\title{
Policy Decisions on Endocrine Disruptors Should Be Based on Science across Disciplines: A Response to Dietrich et al.
}

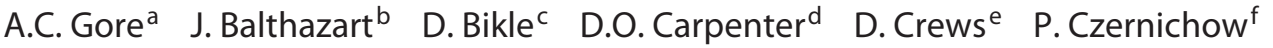

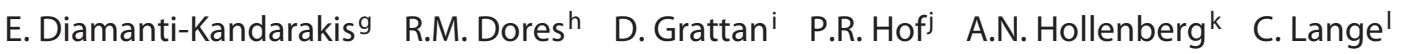 \\ A.V. Lee ${ }^{m} \quad$ J.E. Levine ${ }^{\text {n }}$ R.P. Millar ${ }^{\circ}$ R.J. Nelson ${ }^{p} \quad$ M. Porta ${ }^{q}$ M.Poth ${ }^{r}$ D.M. Power ${ }^{\text {s }}$ G.S. Prins ${ }^{t}$

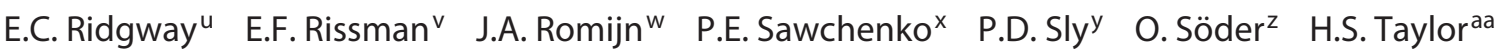 \\ M. Tena-Sempere ${ }^{\text {ab }}$ H. Vaudry ${ }^{\text {ac }}$ K. Wallen ${ }^{\text {ad }}$ Z. Wang ${ }^{\text {ae }} \quad$ L. Wartofsky ${ }^{\text {af }}$ C.S. Watson ${ }^{\text {ag }}$
}

${ }^{a}$ Division of Pharmacology and Toxicology, The University of Texas, Austin, Tex., USA; ${ }^{b}$ University of Liège, GIGA Neurosciences, Liège, Belgium; ' $V A$ Medical Center and University of California, San Francisco, Calif., ${ }^{\mathrm{d} I n s t i t u t e}$ for Health and the Environment, University at Albany, State University of New York, Albany, N.Y., and eSection of

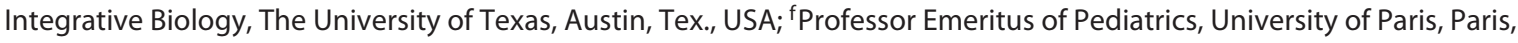
France; ${ }^{9}$ Medical School University of Athens, Sotiria Hospital, Athens, Greece; ${ }^{h}$ Department of Biological Sciences, University of Denver, Denver, Colo., USA; ' Department of Anatomy, University of Otago, North Dunedin, New Zealand; ${ }^{j}$ Icahn School of Medicine at Mt Sinai, New York, N.Y., ${ }^{k}$ Beth Israel Deaconess Medical Center, and Harvard Medical School, Boston, Mass., 'University of Minnesota Masonic Cancer Center, Minneapolis, Minn., 'm University of Pittsburgh Cancer Institute and Magee Women's Research Institute, Pittsburgh, Pa., and nWisconsin National Primate Research Center, Madison, Wisc., USA; ${ }^{\circ}$ UCT/MRC Receptor Biology Unit, University of Cape Town, Cape Town, South Africa; ${ }^{p}$ Department of Neuroscience, The Ohio State University Wexner Medical Center, Columbus, Ohio, USA; ${ }^{9}$ Hospital del Mar Institute of Medical Research and School of Medicine, Universitat Autònoma de Barcelona, Barcelona, Spain; 'Uniformed Services University of the Health Sciences, Bethesda, Md., USA; 's Department of Biosciences, Universidade

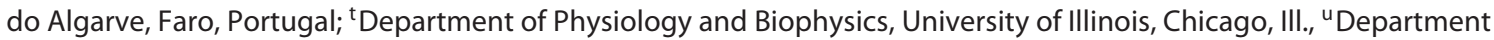
of Medicine, University of Colorado School of Medicine, Denver, Colo., and 'Department of Biochemistry and Molecular Genetics, School of Medicine, University of Virginia, Charlottesville, Va., USA; w'Division of Medicine, Academic Medical Center, University of Amsterdam, Amsterdam, The Netherlands; ${ }^{x}$ Laboratory of Neuronal Structure and Function, The

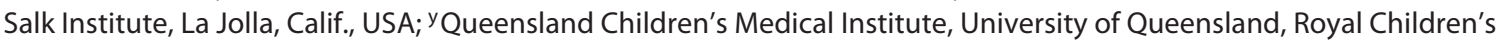
Hospital, Brisbane, Qld., Australia; ${ }^{2}$ Karolinska Institutet at Karolinska University Hospital Solna, Stockholm, Sweden; aa Department of Obstetrics, Gynecology and Reproductive Sciences, Yale School of Medicine, New Haven, Conn., USA;

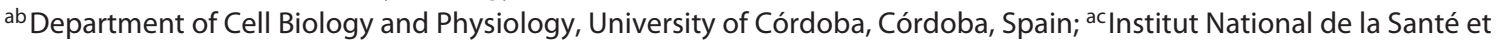

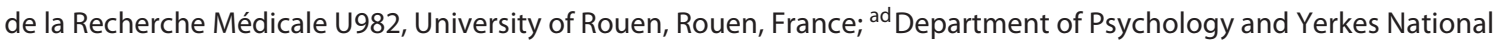

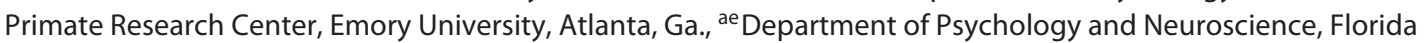

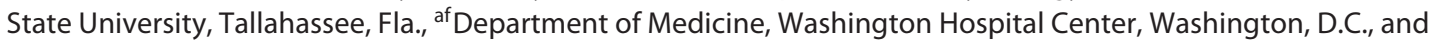
ag Department of Biochemistry and Molecular Biology, University of Texas Medical Branch, Galveston, Tex., USA

\section{KARGER}

E-Mail karger@karger.com www.karger.com/hrp
Andrea C. Gore, PhD, Editor-in-Chief, Endocrinology

Gustavus \& Louise Pfeiffer Professor of Pharmacology \& Toxicology The University of Texas at Austin Austin, TX 78712 (USA)

E-Mail andrea.gore@ austin.utexas.edu 
We are writing as scientists and editors of leading peer-reviewed journals that have published important contributions in the study of endocrine disrupting chemicals (EDCs). By signing this editorial, we affirm that regulatory decisions on EDCs should be made based on the best available science and expertise that involves, among others, reproductive biology, endocrinology, medicine, genetics, behavior, developmental biology, and toxicology [1]. (For a complete list of Signatories and their Disclosures, see online supplementary table 1, www. karger.com/doi/10.1159/000355668.)

Thousands of published studies have revealed the health effects of EDCs on wildlife and laboratory animals and, moreover, have shown associations of EDCs with effects in humans. Many of these studies have been reviewed recently by The Endocrine Society, the United Nations Environment Programme (UNEP) and World Health Organization (WHO), and other independent scientists [2-5]. The conclusions presented in each of these documents are extraordinarily consistent: like hormones, EDCs are active at very low doses and can induce a range of adverse health outcomes, many of which are not examined in traditional toxicology assays [1]. In sum, these reports point to the conclusion that EDCs pose a global health threat.

A recent editorial signed by a number of editors of toxicology journals argues for the status quo in the regulation of EDCs [6], despite the large volume of evidence indicating that current regulations are ineffective in protecting human populations from these chemicals [4-7]. As the UNEP/WHO report notes, the incidence of chronic disease is now greater than that of communicable disease; many of these diseases have an endocrine basis. Both experimental animal and epidemiology studies provide plausible causal links between EDCs and many of these diseases; for some, the data are sufficiently robust [8].

The dismissive approach to endocrine disruption science put forth by Dietrich et al. [6] is unfounded, as it is neither based on the fundamental principles of how the endocrine system works and how chemicals can interfere with its normal function, nor does it consider the consequences of that interference. Their letter also ignores a growing and rigorous body of literature on both endogenous hormonal and exogenous EDC effects.

Basic scientists, clinical investigators, and physicians understand that the endocrine system's functions and responses change remarkably across the life cycle. Of particular concern is incontrovertible evidence, published more than a half century ago $[9,10]$, that there are critical life stages, especially during early development, when hormones dictate the differentiation and development of tissues. Any perturbation of the delicate hormonal balance, whether due to the absence of natural hormones or the presence of exogenous hormones, can have irreversible effects on endocrine-sensitive organs. EDCs are known to upset this delicate balance.

Dietrich et al. [6] also misrepresent the state of science on thresholds, stating that the evidence 'clearly demonstrates the presence of a threshold for nongenotoxic compounds including EDCs'. Dietrich et al. assert that their position constitutes 'common sense' and that the European Commission's approach departs from common sense. They do not, however, provide scientific support for this position. Instead, they list several references [1115] that, upon examination, do not contain data supporting their assumption but rather simply assert that the assumption is true. They also fail to address the considerable literature that speaks against that assumption (e.g. [16-20]). Finally, they argue that structuring regulation upon the assumption of no threshold 'will set an unforeseen precedence [sic]'. This is simply and demonstrably not true. The assumption of no threshold has been widely used, for many years, in the regulation of genotoxic carcinogens, often based on in vitro data. We believe extending this precedent to EDCs is supported by the science [19].

Furthermore, we hold that common sense dictates that policies, particularly those in which public health is at stake, should be based on scientific evidence obtained from the world's leading researchers and should derive from a more evolved, modern understanding of the science, rather than on older, outdated concepts and data taught in classrooms 20 or more years ago. The European Commission policy, by that standard, does represent 'common sense'.

Further, the US National Academy of Sciences has concluded that because of the range of susceptibility to environmental chemicals across the population, such as that from age, preexisting conditions, and genetic variation, and because there are documented exposures to multiple chemicals, including EDCs, in the population, it is more appropriate to consider lack of thresholds at a population level [16].

Many toxicologists have developed rigorous research programs on EDCs that incorporate endocrinological principles, including two former presidents of the Society of Toxicology, Cheryl Walker and Linda Birnbaum. They and many other toxicologists do work in this area and report results that have contributed to the breadth and 
depth of concern about EDCs as a global public health threat. The ad hominem attacks in Dietrich et al. [6] do nothing to advance science or opportunities to protect public health; we refer readers to two additional responses to their editorial that support this point of view [21,22]. We need the fields of toxicology, endocrinology and other stakeholders to work together to address these issues, not engage in recriminations.

Policymakers in Europe and elsewhere should base their decisions on science, not on assumptions based on principles that arose out of research on chemicals that are not EDCs. The letter by Dietrich et al. does the European Commission, science, including the field of toxicology, and most importantly, public health, a profound disservice.

\section{Acknowledgements}

The following is the list of signatories. The complete list of their affiliations and disclosure information is provided in online supplementary table 1 .

\section{Signatories}

Journal Editors-in-Chief

1 Prof. Jacques Balthazart, $\mathrm{PhD}$, Frontiers in Neuroendocrinology

2 David O. Carpenter, MD, Reviews on Environmental Health

3 Paul Czernichow, MD, Hormone Research in Paediatrics

4 Donald B. DeFranco, PhD, Molecular Endocrinology

5 Robert M. Dores, $\mathrm{PhD}$, General and Comparative Endocrinology

6 Andrea C. Gore, PhD, Endocrinology

7 David Grattan, PhD, Journal of Neuroendocrinology

8 Stephen R. Hammes, MD, PhD, Editor-in-Chief elect, Molecular Endocrinology

9 Patrick R. Hof, MD, Journal of Comparative Neurology

10 Carol Lange, $\mathrm{PhD}$, Hormones and Cancer

11 Jon E. Levine, PhD, Frontiers in Neuroendocrinology

12 Deborah M. Power, PhD, General and Comparative Endocrinology

13 Professor Robert P. Millar, PhD, FRSE, Neuroendocrinology

14 E. Chester Ridgway, MD, MACP, Endocrine Reviews

15 Johannes A. Romijn, MD, PhD, European Journal of Endocrinology

16 Peter D. Sly, MBBS, FRACP, MD, DSc, Reviews on Environmental Health

17 Hubert Vaudry, PhD, DrSci, Frontiers in Neuroendocrine Science; also Senior Editor, Journal of Neuroendocrinology; Associate Editor, Hormone and Metabolic Research; Associate Editor, General and Comparative Endocrinology; Associate Editor, Peptides

18 Kim Wallen, $\mathrm{PhD}$, Hormones and Behavior

19 Leonard Wartofsky, MD, MACP, Journal of Clinical Endocrinology and Metabolism

20 Cheryl S. Watson, $\mathrm{PhD}$, Endocrine Disruptors
Journal Associate Editors

1 Åke Bergman, $\mathrm{PhD}$, Archives of Environmental

Contamination and Toxicology; Environmental Science and Pollution Research

2 Daniel Bikle, MD, PhD, Endocrinology

3 Barbara A. Cohn, PhD, Endocrine Disruptors

4 David Crews, PhD, Endocrine Disruptors; Journal of

Experimental Zoology; Ecological Genetics and Physiology;

Sexual Development; Epigenetics

5 Peter L. DeFur, PhD, Endocrine Disruptors

6 Evanthia Diamanti-Kandarakis, MD, PhD, European Journal of Endocrinology

7 Anthony N. Hollenberg, MD, Endocrinology

8 Susan Jobling, $\mathrm{PhD}$, Endocrine Disruptors

9 Jun Kanno, MD, PhD, Environmental Health Perspectives

10 Carolyn Klinge, $\mathrm{PhD}$, Endocrine Disruptors

11 B. Paige Lawrence, $\mathrm{PhD}$, Endocrine Disruptors

12 Adrian V. Lee, $\mathrm{PhD}$, Endocrinology

13 J. P. Myers, PhD, Endocrine Disruptors

14 Randy J. Nelson, PhD, Hormones and Behavior

15 Miquel Porta, MD, MPH, PhD, Journal of Epidemiology \& Community Health; European Journal of Clinical

Investigation; European Journal of Epidemiology

16 Merrily Poth, MD, Journal of Clinical Endocrinology and Metabolism

17 Gail S. Prins PhD, Endocrinology; Andrology

18 Emilie F. Rissman, $\mathrm{PhD}$, Endocrinology

19 Paul E. Sawchenko, PhD, Journal of Comparative Neurology

20 Olle Söder, MD, PhD, Hormone Research in Paediatrics

21 Ana M. Soto, MD, Progress in Biophysics and Molecular Biology

22 Shanna Swan, PhD, Endocrine Disruptors

23 Hugh S. Taylor, MD, Endocrinology

24 Manuel Tena-Sempere, $\mathrm{MD}, \mathrm{PhD}$, Endocrinology

25 Frederick vom Saal, $\mathrm{PhD}$, Endocrine Disruptors

26 Zuoxin Wang, PhD, Hormones and Behavior

27 Wade V. Welshons, PhD, Endocrine Disruptors

28 R. Thomas Zoeller, PhD, Endocrine Disruptors

\section{Additional Signatories}

1 Benson T. Akingbemi, PhD

2 Koji Arizono, PhD

3 Scott M. Belcher, $\mathrm{PhD}$

4 Fiorella Belpoggi, $\mathrm{PhD}$

5 Carl-Gustaf Bornehag, PhD

6 Jean-Pierre Bourguignon, $\mathrm{MD}, \mathrm{PhD}$

7 Terry R. Brown, PhD

8 Ernesto Burgio, MD

9 Terrence J. Collins, PhD

10 D. Andrew Crain, $\mathrm{PhD}$

11 Barbara Demeneix, $\mathrm{PhD}$

12 Rodney R. Dietert, PhD

13 Loretta Doan, $\mathrm{PhD}$

14 Thea M. Edwards, PhD

15 Mariana F. Fernandez, PhD

16 R. William Field, PhD, MS

17 Linda C. Giudice, MD, PhD

18 Louis J. Guillette, PhD

19 Y. Leon Guo, MD, PhD, MPH

20 Tyrone Hayes, PhD 
21 Andrea Hinwood, $\mathrm{PhD}$

22 C. Vyvyan Howard, MB, ChB, PhD, FRCPath

23 Eric R. Hugo, PhD

24 Patricia Hunt, $\mathrm{PhD}$

25 Taisen Iguchi, $\mathrm{PhD}$

26 Richard J. Jackson, MD, MPH, AIA (Hon), ASLA (Hon)

27 Patricia Joseph-Bravo, $\mathrm{PhD}$

28 Hans Laufer, $\mathrm{PhD}$

29 Duk-Hee Lee, MD, PhD

30 Rachel Morello-Frosch, PhD, MPH

31 Jane Muncke, PhD

32 Angel Nadal, PhD

33 David O. Norris, $\mathrm{PhD}$

34 Jörg Oehlmann, PhD

35 Nicolas Olea, $\mathrm{MD}, \mathrm{PhD}$

36 Edward F. Orlando, PhD

37 Vasantha Padmanabhan, $\mathrm{PhD}$

38 Paola Palanza, PhD
39 Stefano Parmigiani, $\mathrm{PhD}$

40 Donald W. Pfaff, PhD

41 Beverly S. Rubin, PhD

42 Joan V. Ruderman, $\mathrm{PhD}$

43 Arnold Schecter, MD, MPH

44 Toshi Shioda, MD, PhD

45 Martin Scheringer, $\mathrm{PhD}$

46 Niels E. Skakkebaek, MD

47 Howard M. Snyder III, MD

48 Carlos Sonnenschein, MD

49 Richard W. Stahlhut, MD, MPH

50 Laura Vandenberg, PhD

51 Catherine VandeVoort, $\mathrm{PhD}$

52 Martin Wagner, $\mathrm{PhD}$

53 Hong-Sheng Wang, PhD

54 Bernard Weiss, $\mathrm{PhD}$

55 Teresa Woodruff, PhD

56 Tracey Woodruff, $\mathrm{PhD}$

\section{References}

1 American Society of Human Genetics, American Society for Reproductive Medicine, Endocrine Society, Genetics Society of America Society for Developmental Biology, Society for Pediatric Urology, Society for the Study of Reproduction, Society for Gynecologic Investigation. Assessing chemical risk: societies offer expertise. Science 2011;331:1136.

-2 Diamanti-Kandarakis E, Bourguignon JP, Giudice LC, et al: Endocrine-disrupting chemicals: an Endocrine Society scientific statement. Endocr Rev 2009;30:293-342.

- 3 Vandenberg LN, Colborn T, Hayes TB, et al: Hormones and endocrine-disrupting chemicals: low-dose effects and nonmonotonic dose responses. Endocr Rev 2012;33:378-455.

-4 Zoeller RT, Brown TR, Doan LL, et al: Endocrine-disrupting chemicals and public health protection: a statement of principles from the Endocrine Society. Endocrinology 2012;153: 4097-4110.

5 Bergman A, Heindel JJ, Jobling S, Kidd KA, Zoeller RT (eds): State of the Science of Endocrine Disrupting Chemicals - 2012. An Assessment of the State of the Science of Endocrine Disruptors Prepared by a Group of Experts for the United Nations Environment Programme and World Health Organization. Geneva, Switzerland: United Nations Environment Programme and the World Health Organization; 2013.

-6 Dietrich DR, Aulock SV, Marquardt H, et al: Scientifically unfounded precaution drives European Commission's recommendations on EDC regulation, while defying common sense, well-established science and risk assessment principles. Chem Biol Interact 2013; 205:A1-A5.
7 Vandenberg LN, Colborn T, Hayes TB, et al: Regulatory decisions on endocrine disrupting chemicals should be based on the principles of endocrinology. Reprod Toxicol 2013;38: $1-15$.

8 Birnbaum LS: Environmental chemicals: evaluating low-dose effects. Environ Health Perspect 2012;120:A143-A144.

9 Phoenix CH, Goy RW, Gerall AA, Young WC: Organizing action of prenatally administered testosterone propionate on the tissues mediating mating behavior in the female guinea pig. Endocrinology 1959;65:369-382.

10 Wallen K: The Organizational Hypothesis: reflections on the 50th anniversary of the publication of Phoenix, Goy, Gerall, and Young (1959). Horm Behav 2009;55:561-565.

11 Boobis AR, Daston GP, Preston RJ, Olin SS: Application of key events analysis to chemical carcinogens and noncarcinogens. Crit Rev Food Sci Nutr 2009;49:690-707.

12 Borgert CJ, Sargent EV, Casella G, Dietrich DR, McCarty LS, Golden RJ: The human relevant potency threshold: reducing uncertainty by human calibration of cumulative risk assessments. Regul Toxicol Pharmacol 2012;62: 313-328.

13 Piersma AH, Hernandez LG, van Benthem J, et al: Reproductive toxicants have a threshold of adversity. Crit Rev Toxicol 2011;41:545554 .
14 Rhomberg LR, Goodman JE, Haber LT, et al: Linear low-dose extrapolation for noncancer health effects is the exception, not the rule. Crit Rev Toxicol 2011;41:1-19.

15 Rhomberg LR, Goodman JE: Low-dose effects and nonmonotonic dose-responses of endocrine disrupting chemicals: Has the case been made? Regul Toxicol Pharmacol 2012;64: 130-133.

16 vom Saal FS, Sheehan DM: Challenging risk assessment. Forum Appl Res Public Policy 1998; 13:11-18

17 Sheehan DM, Willingham E, Gaylor D, Bergeron JM, Crews D: No threshold dose for estradiol-induced sex reversal of turtle embryos: how little is too much? Environ Health Perspect 1999;107:155-159.

18 Sheehan DM, vom Saal FS: Low dose effects of hormones: a challenge for risk assessment. Risk Policy Rep 1997;4:31-39.

19 Sheehan DM: No-threshold dose-response curves for nongenotoxic chemicals: findings and applications for risk assessment. Environ Res 2006;100:93-99.

20 Welshons WV, Thayer KA, Judy BM, Taylor JA, Curran EM, vom Saal FS: Large effects from small exposures. I. Mechanisms for endocrine-disrupting chemicals with estrogenic activity. Environ Health Perspect 2003;111: 994-1006.

21 Grandjean P, Ozonoff D: Transparency and translation of science in a modern world. Environ Health 2013;12:70.

22 Bergman A, Andersson AM, Becher G, et al: Science and policy on endocrine disrupters must not be mixed: a reply to a 'common sense' intervention by toxicology journal editors. Environ Health 2013;12:69. 